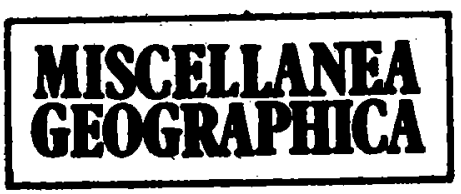

WARSZAWA 1990

Andrzej Musiał

\title{
POLAR RESEARCH OF THE FACULTY OF GEOGRAPHY AND REGIONAL STUDIES OF THE UNIVERSITY OF WARSAW AT SPITSBERGEN IN THE YEARS 1980-1988
}

Expeditions to Spitsbergen were initiated by students of the Geographic Scientific Circle, who organized a reconnaissance trip to Western Spitsbergen in the summer of 1978 (July 5 - September 9). Scientific supervision on behalf of the Faculty was performed by Dr W. Lenart (hydrologist). The next three trips: in 1980 (July 7 - September 9), 1985 (July 2 - September 5) and 1988 (June 28 - August 26) were organized by research workers and students of the Faculty of Geography and Regional Studies of the University of Warsaw. Dr A. Musial (geomorphologist) was the scientific and organizational manager. Besides, the following employees of the Faculty took part in Academic Polar Expeditions of the University of Warsaw: Dr B. Horodyski (cartographer), K. Kossobudzki, M.Sc. (cartographer) and J. Drecki, M.Sc. (geomorphologist). Since 1985, invited geographers from other countries have participated in the expeditions, that is a Slovak J. Lácika (structural geomorphologist) and three Swedes, including Prof. W. Karlen (glaciologist). Overall, the Academic Polar Expeditions organized by the Faculty of Geography and Regional Studies of the University of Warsaw were attended by: 5 employees, 3 doctors of medicine, 1 journalist, 4 foreign guests and 21 students.

The transport to Spitsbergen was organized by air from Warsaw to Moscow, then to Longyearbyen and afterwards in Soviet helicopters to Barentsburg. Transport to the main bases, that is trappers' cottages, was organized in helicopters or by ship.

Field studies in small groups of people were conducted from tent bases. Food and measuring instruments were supplied from Poland to the main bases by air from Barentsburg or by sea on a Polish ship from Gdynia.

The area of scientific penetration in three subsequent Academic Polar Expeditions of the Faculty of Geography and Regional Studies 
of the University of Warsaw covered the western part of Nordenskiöld Land and stretched between Bellsund and Van Mijenfjorden in the south and Isfjorden in the north. The research program of the expeditions included physicogeographical issues with specific stress on problems related to geomorphology, geology and glaciology. So far about $700 \mathrm{~km}^{2}$ of the western part of Nordenskiöld Land has been geologically and geomorphologically charted on the scale of $1: 25,000$ with the use of air pictures and panoramic photos from mountain peaks. The collected materials helped to publish two, colour geomorphological maps of the studies area on the scale of $1: 75,000$ and a plan on the scale of $1: 3,000$ of a marginal zone of Linnues glacier, based on a table photo. Studies also included the situation of the so-called "old" moraimic belt on the sea plain as well as the distribution of erratics in that part of the archipelago. Also detailed botanic studies were made of a fragment of the tundra near Värsolhytta. Now there is a possibility of a synthetic study presenting paleographic development of the area under study. So far about twenty articles have been published on the issue (a list of the most important ones is herebelow).

\section{LITERATURE}

Gogolek, W., Lewandowski, W., 1980, "Preliminary geomorphological characteristics of Linèdalen", Polish Polar Research, No. 4.

Horodyski, B, Kossobudzki, K., Musiał, A., 1988, "The use of panoramic ground-photographs in geomorphological mappings of polar regions. Example from West Spitsbergen", Miscellanea Geographica, Uniwersytet Warszawski, Warszawa, pp. 79-83.

Horodyski, B., Kos s obudzki, K., M usial, A., 1987, „Wykorzystanie panoramicznych zdjęć naziemnych do kartowania geomorfologicznego obszarów polarnych" (The use of panoramic ground-photographs in geomorphologic mapping of polar regions), Fotointerpretacja $w$ badaniach polarnych, Toruń, pp. $40-45$.

K enig, A., 1981, "Charakterystyka hydrologiczna doliny Linneusza” (Hydrological characteristics of Linneus Valley), in: Materialy Studenckiej Sesji Polarnej, Warszawa, pp. $\mathbf{5 1 - 5 8 .}$

Lá cika, J., M usia k, A., 1988, "Relief-forming processes in the polar zorie. Example from Nordenskiöld Land (West Spitsbergen)"; Miscellanea Geographica, pp. 69-77.

I. e wa n d ow ska, J., 1981, „Prace topograficzne II Polarnej Wyprawy Śludentów Geografii Uniwersytetu Warszawskiego "Spitsbergen 80" (Topographic works of the Second Polar Expedition of Geography of Warsaw University "Spitsbergen 80"), in: Materialy Studenckiej Sesji Polarnej, Warszawa, pp. 13-18.

Miros, K., „Geneza i rozmieszczenie bagien w dolinie Linneusza" (The origin and location of swamps in the Linneus Valley), in: Materiaty Studenckiej Sesji Polarnej, Warszawa, pp. 69-74. 
Musia 1, A., 1981, „Badania geomorfologiczne w NW części Ziemi Nordenskiölda (Spitsbergen Zachodni)" (Geomorphological Studies in the north-western part of Nordenskiöld Land (West Spitsbergen)), in: Materiaty Studenckiej Sesji Polarnej, Warszawa, pp. $19-30$.

M u s i a 1, A., 1983, „Głazy narzutowe w NW części Ziemi Nordenskiölda” (Erratic boulders in the north-western part of Nordenskiöld Land), in: Polskie badania polarne 1970-1982, Torun, pp. 150-155.

M u s i a 1, A., 1984, "Ancient glaciations in the north-western part of Nordenskiöld Land and their extent in the light of characteristic occurrence of erratics", Miscellanea Geographica, Warszawa, pp. 57-65.

Musiał, A., 1984, "Ancient glaciations in the north-western part of Nordenskiold Land", Resumés des communications à $25^{e}$ Congrès International de Géographie, Tome I, Paris.

M u s i a . A.. 1985, "Traces of the glaciations in the north-western part of Nordenskiöld Land (West Spitsbergen)", Polish Polar Research, Vol. 6, No. 4, pp. 497-513.

Prószyńska, H., 1981, „Okolice doliny Linneusza - swoisty przykład spitsbergenskiej ekumeny" (The vicinity of the Linneus Valley: a chararteristic example of Spitsbergen ecumene), in: Materiaty Studenckiej Sesji Polarnej, Warszawa, pp. 85-94.

R y ży k, E., 1981, "Charakterystyka geomorfologiczna marginalnej strefy lodowca Linneusza" (Geomorphological characteristics of the marginal zone of the Linneus glacier), in: Materiaty Studenckiej Sesji Polarnej, Warszawa, pp. 31-40.

S a r u 1, J., 1981, "Badania stosunków wodnych tundry dolnej części zlewni Linneélva na Ziemi Nordenskiölda (Spitsbergen Zachodni)" (Studies on water relations in the tundra in the lower part of the Linneélva catchment area in Nordenskiöld Land (West Spitsbergen)), in: Materiały Studenckiej Sesji Polarnej, Warszawa, pp. 59-68.

S moleński, W., 1981, "Ogólna charakterystyka lodowca Linneusza" (General characteristics of the Linneus glacier), in: Materialy Studenckiej Sesji Polar$n e j$, Warszawa, pp. $41-54$.

S molénski, W., 1981, "Rzeźbotwórcza rola śnieżników Vardeborgsletta" (Relief-forming role of the Vardeborgsleta snow mountains), in: Materialy Studenckiej Sesji Polarnej, Warszawa, pp. 75-84.

\section{MAPS PUBLISHED}

Horodyski, B., Lewand owska, J., Mal a nowski, T., 1981, Strefa marginalna lodowca Linneusza, $1: 3,000$ (The Marginal Zone of Linneus Glacier, $1: 3,000$ ), Katedra Kartografii, Wydzial Geografii i Studiów Regionalnych, Uniwersytet Warszawski.

M u siał, A., 1982, Mapa geomorfologiczna Ziemi Nordenskiölda (część N), $1: 75,000$ (Geomorphological Map of Nordenskiöld Land (northern part), 1:75,000), Katedra Kartografii, Wydział Geografii i Studiów Regionalnych, Uniwersytet Warszawski.

M u s i a 1, A. et al., 1988, Geomorphological Map of Nordenskiöld Land (West Spitsbergen), $1: 75,000$, Katedra Kartografii, Wydzial Geografii i Studiów Regionalnych, Uniwersytet Warszawski. 
